\title{
Mineralogical Investigation and Washability Treatment of the Nickeliferous Lateritic Deposit of Nome (Albania)
}

\author{
Nikolaos Katzagiannakis, Georgios Alevizos, Elias Stamboliadis, Antonios Stratakis, \\ Evaggelos Petrakis \\ School of Mineral Resources Engineering, Technical University of Crete, Chania, Greece \\ Email: nkatzagiannakis@isc.tuc.gr, alevizos@mred.tuc.gr, elistach@mred.tuc.gr, astratak@mred.tuc.gr, \\ vpetraki@mred.tuc.gr
}

Received 21 May 2014; revised 19 June 2014; accepted 19 July 2014

Copyright (C) 2014 by authors and Scientific Research Publishing Inc.

This work is licensed under the Creative Commons Attribution International License (CC BY). http://creativecommons.org/licenses/by/4.0/

(c)

\section{Abstract}

The Nome nickel laterite deposit is located in the North East of Albania. The ore deposit, developed between ultramafic rocks and limestones during Early Cretaceous to Eocene, represents part of the Albanian Mirdita ophiolite zone. The lateritization of the deposit was observed mainly in three separate areas, the Has-Kukes-Lure in the North, Pogradec-Librazhd in the center and Devoll in the South. The main mineralogical components of the ore are goethite, hematite and quartz, while the secondary ones are chlorite (clinochlore, Ni-chlorite), kaolinite and lizardite. Nickel is mainly found in chlorite. The ore is characterized by the presence of spheroid particles, such as oval, pisoid, peloid and composite spheroid. According to the microscopical examination the ore is characterized in general as allotriomorphic, inequigranular and the texture is oolitic-pisolitic. For the mineral processing gravimetric and magnetic separation are used in the size fractions $\mathbf{- 8}+4$ $\mathrm{mm},-4+1 \mathrm{~mm},-1+0.250 \mathrm{~mm}$ and $-0.250+0.063 \mathrm{~mm}$. The chemical and mineralogical analyses, as well as the microscopic examination have shown that mineral processing by magnetic separation gives the most satisfactory results for the size fractions $-1+0.250 \mathrm{~mm}$ and $-0.250+0.063$ mm.

\section{Keywords}

Nickeliferous Lateritic Deposit, Mineral Processing, Magnetic Separation, Ore Microscopy, Nome

\section{Introduction}

Nickel is one of the most common elements in the earth. It is found as sulfides, oxides and inorganic salts. The

How to cite this paper: Katzagiannakis, N., Alevizos, G., Stamboliadis, E., Stratakis, A. and Petrakis, E. (2014) Mineralogical Investigation and Washability Treatment of the Nickeliferous Lateritic Deposit of Nome (Albania). Geomaterials, 4, $105-115$. http://dx.doi.org/10.4236/gm.2014.43011 
physical properties that illustrates are very important and provide an extended variety of applications in the industrial area more than any other metal element. The main uses of nickel alloys and stainless steels are in engineering, transportation, metal goods, electro \& electronic, building \& construction etc. Worldwide major nickel production countries are the United States, Cuba, Canada, Indonesia, South Africa, Russia, Brazil, China, Philippines, Australia, Greece and others. Nickeliferous ores are classified according to their genesis into three categories: sulfurous, lateritic and sedimentary [1]. The sedimentary nickeliferous ores are usually produced by the lateritic ones through the weathering and transportation. Nickel has a mean composition in ores about $0.97 \%$, where sulfurous ores contain $0.58 \% \mathrm{Ni}$ and lateritic ores $1.32 \%$. The main nickeliferous ores worldwide are lateritic (72\%) [2]. According to Kuck [3], the nickeliferous ore deposits worldwide contain about 130 million tones of $\mathrm{Ni}, 60 \%$ of this amount is contained in lateritic ore deposits and the remaining $40 \%$ in sulfurous ore deposits. Global nickel production originates $40 \%$ from lateritic deposits and $60 \%$ from sulphide deposits [4]. The ores are residual deposits of lateritic weathered crust of ultramafic rocks with a significant financial significance according to their composition of nickel and cobalt. About 85\% of lateritic nickeliferous ore deposits are developed in ophiolitic zones. Most lateritic deposits are developed on the surface without overlaid covers. It has to be mentioned that some of the deposits on the Balkanic area are an exception where there is a bedrock cover of limestone, without a standard thickness and this cover functions like a shield to the lower lateritic bedrock. Lateritic nickeliferous ore deposits are divided into three zones, the limonite zone, the clay zone and the saprolite zone. The major minerals found in lateritic ores are goethite and/or hematite, chlorite (clinochlore, Ni-chlorite), nickel smectites (Ni-notronite, Ni-montmorillonite, Ni-saponite), while minor minerals are kaolinite, chromite, serpentine (nepouite), talc (willemseite), quartz and calcite.

A representative nickeliferous ore in the Balkans is found in the Mirdita zone (Northern Albania). The Mirdita zone corresponds to a large ophiolitic complex being representative of the Hellenic-Dinaric orogenic belt. The ophiolites are subdivided into two different sequences, known as the Western and Eastern ophiolitic belt. The ferruginization in the Mirdita zone was developed during the Early Cretaceous to the Eocene and can be divided in three different areas. The North area is developed in the Has-Kukes-Lure region, the center in the PogradecLibrazhd region, while the South is developed in the Devolli region. In the Devolli and Kukes areas together with the nickeliferous ore aspect a nickel-silica (Ni-Si) ore with the concentration of nickel to be approximately $1.1 \%-1.4 \%$. The total amount of nickeliferous ore in these areas is 230 million tones and the amount of Ni-Si ore is estimated about 81.4 million tones [5] [6].

\section{Geology}

The Pindos Zone ophiolite belt in Albania is sandwiched between the Apulian platform in the west and the Korabi-Pelagonian platform in the east. The Apulian platform units collectively form the eastern edge of the Apulian microcontinent that is underplating Eurasia along an oblique collision zone Apulian tectonic zone occurs in the southern part of the Dinarides facing the Mirdita ophiolite belt. Composed of intensely deformed Upper Paleozoic-Mesozoic siliciclastic and carbonate rocks of the Malesia e Madhe and Valbona subzones, this zone constitutes the Albanian Alps, where the stratigraphically lower levels (Permian and older?) of the Apulian platform edge are exposed. In the Pindos-Mirdita, the existence of serpentinite clasts in the Middle Jurassic conglomerate in the Rubik area suggests that serpentinized upper mantle peridotites were already exposed on the seafloor, providing sediments to the depocenters(s) of the rift-drift assemblages [7] [8].

The Mirdita zone is the expansion of two ophiolitic zones, Shkoder-Peje (Dinarides) from the north and Albania (Hellinides) from the south [9] [10]. The Kukes mafic-ultramafic massif belongs to the Albanian Mirdita zone and is representative of the tectonic environment of Alps (Figure 1). The lithological stratigraphy of mafic-ultramafic rocks is from bottom to top: the harzburgite zone, the harzburgite-dunite zone, the massive dunite zone, the intermediate zone and the gabbros zone. The Upper Triassic-Lower Jurassic limestones southeast of the Kukes ultramafic massif are composed of grey neritic limestones, locally containing stromatolites and fragments of megalodontes [11]. On the area of Has-Kukes-Lure is situated a large alpine ophiolitic complex which starts from the area of Has in the border with Kosovo. It extends for $70 \mathrm{Km}$ south on the area of Macukulli. Significant nickeliferous deposits are grown up on ultramafic rocks (harzburgites-serpentines) in the Mamez, Trull Surroj and Nome area, which are covered by limestones of the Early Cretaceous [5]. The nickeliferous deposit of Nome is in the form of bedrock with length $1.5 \mathrm{Km}$ approximately and thickness that ranges from 5 to $20 \mathrm{~m}$. All deposits show a big concentration on iron, while there is a small development of a saprolite zone. The estimations show a nickeliferous deposit of 70 million tones with a concentration of $1.00 \% \mathrm{Ni}$ and $0.05 \%$ Co [1]. 


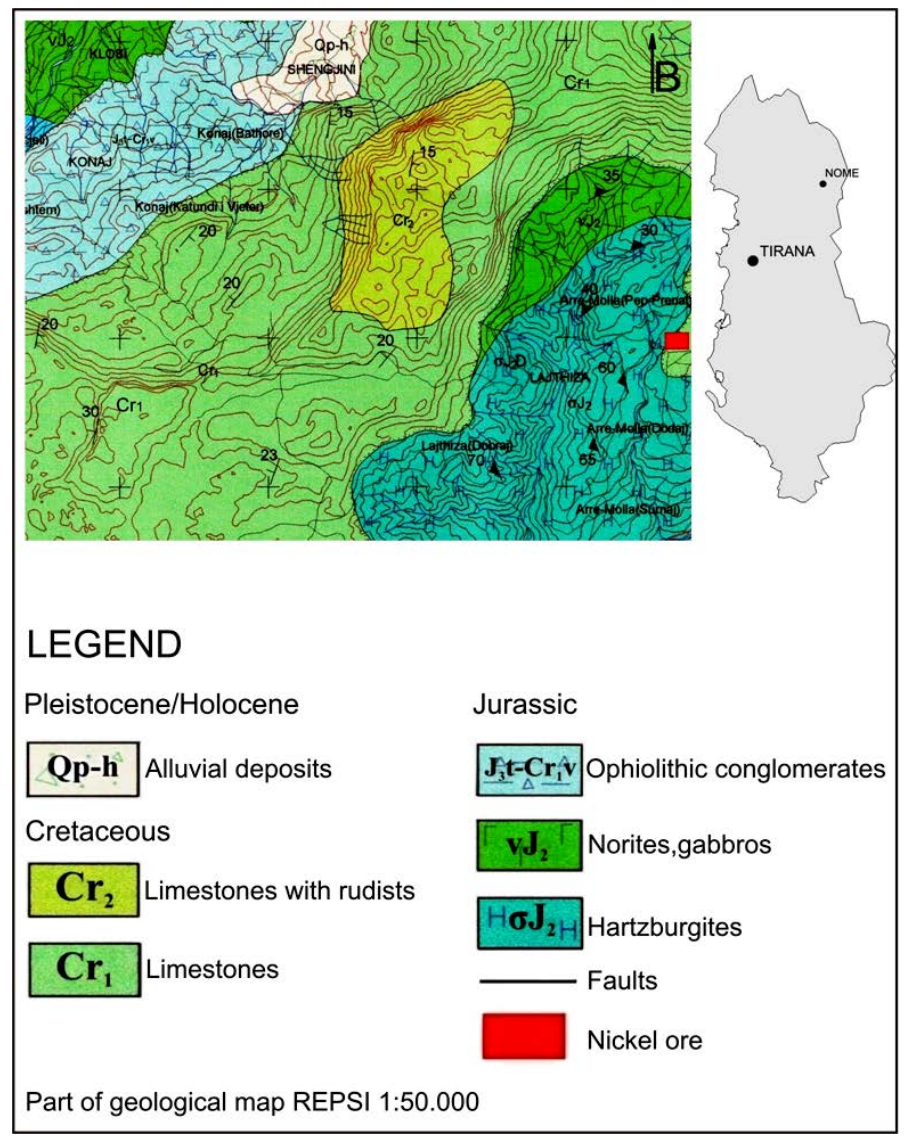

Figure 1. Modified geological map of Nome area.

\section{Experimental}

The mineralogical examination of the nickeliferous ore was carried out using the $\mathrm{X}$-ray diffraction method (XRD). The automated X-ray diffractometer, D8 Advance of Bruker AXS company was used. The identification of the ore minerals and the description of the fabric, as well as, the examination of the intergrowth in the different products were performed via ore microscopy. A JENA ore microscope equipped with an OLYMPUS digital camera was used. The chemical analysis of nickeliferous ore was carried out using the automated X-ray fluorescence spectrometer (XRF), Bruker S2 Ranger. For the gravimetric separation of nickeliferous ore samples, a mixture of liquid Tetrabromoethane and Carbon Tetrachloride was used, with density of the $d=2.70 \mathrm{~g} / \mathrm{cm}^{3}$. The magnetic separation was performed with the Perm Roll magnetic separator made by IMPROSYS, as well as, with the high intensity Induced Roll Magnetic Separator MIH 111-5 made by Carpco.

\section{Mineralogy}

The nickeliferous ore deposit of the area is mainly ferrous and it constitutes of a lateritic crust weathered zone in contact with a saprolite zone in much smaller development. The ore sampling was held on the area of Kukes in Nome. The collected samples were taken from a representative section of the exposed face of the deposit from the base to the top.

The microscopic examination and x-ray diffraction analysis (Figure 2) of the bottom section of the deposit which is the ultramafic rocks, showed that it consists mainly of hematite and occasionally some chromite was also observed. Hematite is found in a form of microcrystal agglomerates. Further the saprolite zone consists mainly of quartz and occasionally was observed clinochlore, goethite and hematite. According to the microscopic examination quartz was mainly formed on compact masses and on partly rounded grains, while there were some special cases in which quartz exists in microcrystal agglomerates in form of veins. In the saprolite 


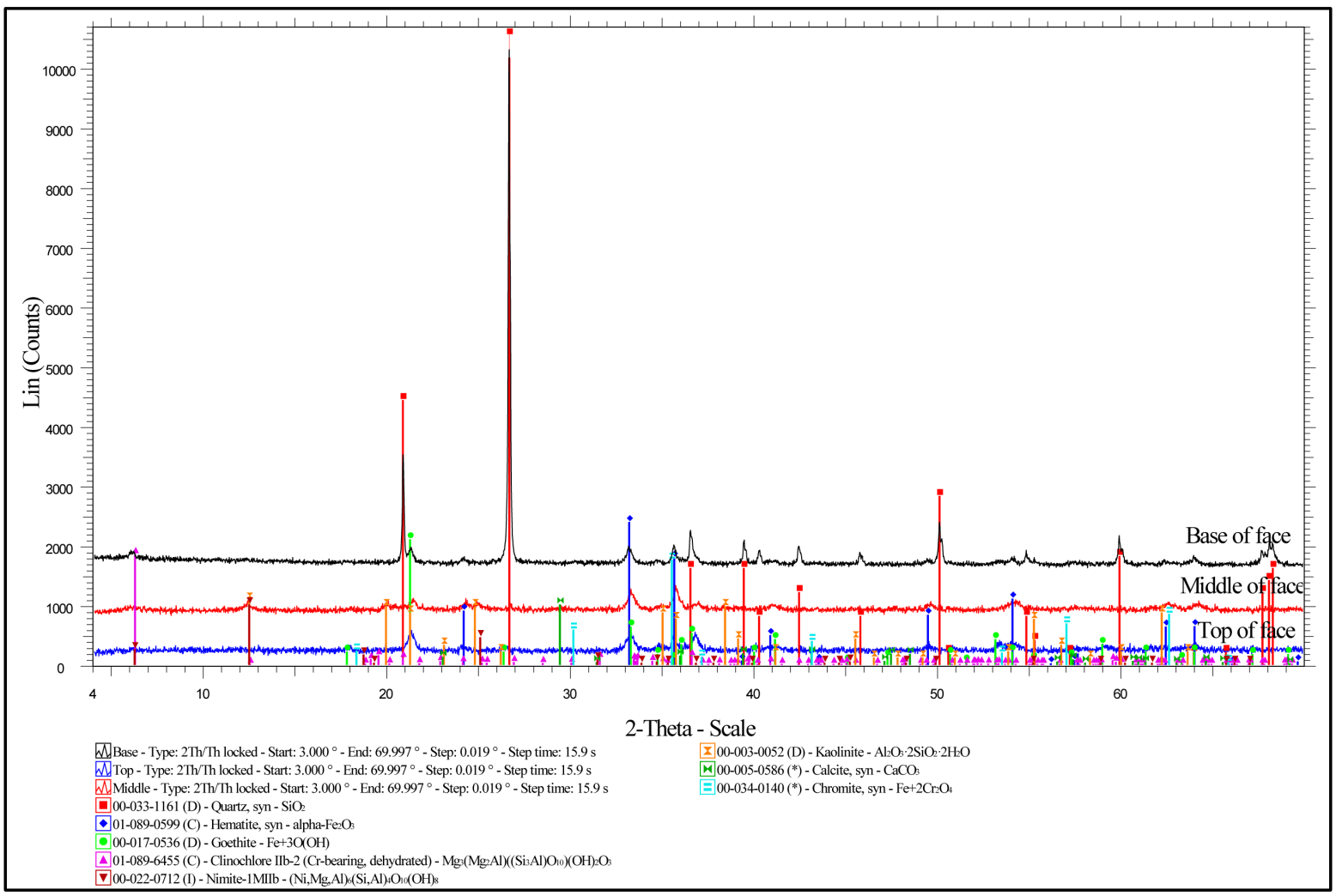

Figure 2. X-ray diffraction patterns of representative samples from different point of the exposed face.

zone the ferrous phase is goethite that alters gradually into hematite. The binder material between quartz grains is particularly clinochlore. Next zone is the clay ore which has a thickness of $1 \mathrm{~m}$ approximately and mainly consists of kaolinite, hematite, goethite and minor in nickeliferous chlorite, quartz and calcite. The microscopic examination showed the existence of ooids, peloids, pisoids and complex spheroids which are consisting of hematite. Goethite is found as ooids and peloids shells. The ooids and peloids are observed to be concentric shells with multiple cracks which are related to the dehydration of the goethite which is alterated into hematite (Figure 3). Complex spheroids that include ooids, peloids and some clastic grains of chromite and quartz were also observed (Figure 4). The binder material is composed of kaolinite, nickeliferous chlorite and calcite, while scattered clastic grains of chromite and quartz were observed. The upper zone of the nickeliferous ore deposit is the pisolitic zone with a thickness of $9 \mathrm{~m}$. A large number of spheroids were found in pisolitic zone, while the main mineralogical constituents are hematite and goethite. Peloids exist in a larger extent in comparison with other spheroids, found in the form of clastic grains in the binder material. The majority of the peloids have multiple cracks and are composited of hematite. Ooids and pisoids have a concentric texture, that shows the formation process and reveals the transfer process and deposition of the clastic sediment The complex spheroids constitute the basic component of the pisolitic ore and their size varies The main mineralogical component of these complex spheroids is hematite and secondarily goethite. The complex spheroids have been embedded with a form of inclusions (intergranular texture). Also in this pisolitic layer scattered crystals of chromite and quartz are found in the binder material between the grains. The chromite crystals have multiple cracks due to the tectonic strain (cataclastic texture) (Figure 5). The binder material, on the pisolitic layer, is mainly composed of clinochlore and secondary of nickel chlorite and kaolinite.

The chemical analyses of representative samples collected from the exposed face of the nickeliferous ore deposit from the base to the top are presented in Table 1.

The $\mathrm{SiO}_{2}$ is present mainly in quartz and secondary in other silicate minerals (chlorite, serpentine, talc and illite), while the $\mathrm{Fe}_{2} \mathrm{O}_{3}$ is present mainly in ferrous minerals (hematite and goethite) and secondary in chlorite and chromite. Nickel is present mainly in chlorite minerals (nickel chlorite or nimite) and secondary in ferrous minerals like serpentine, which is part of binder material between the grains (Figure 5). 


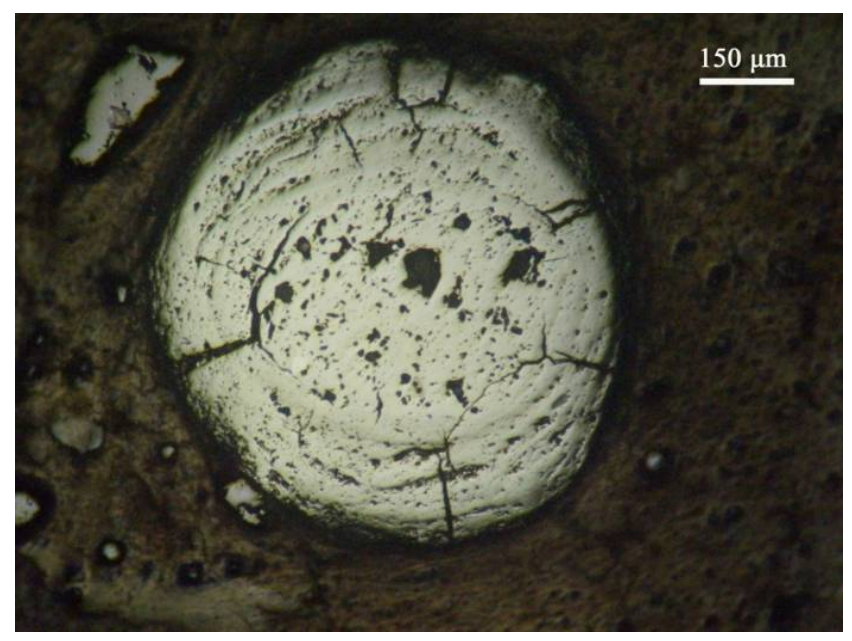

Figure 3. Ooid of hematite with multiple cracks which is surrounded by goethite. Sample AK7, Reflected light, // Nicols.

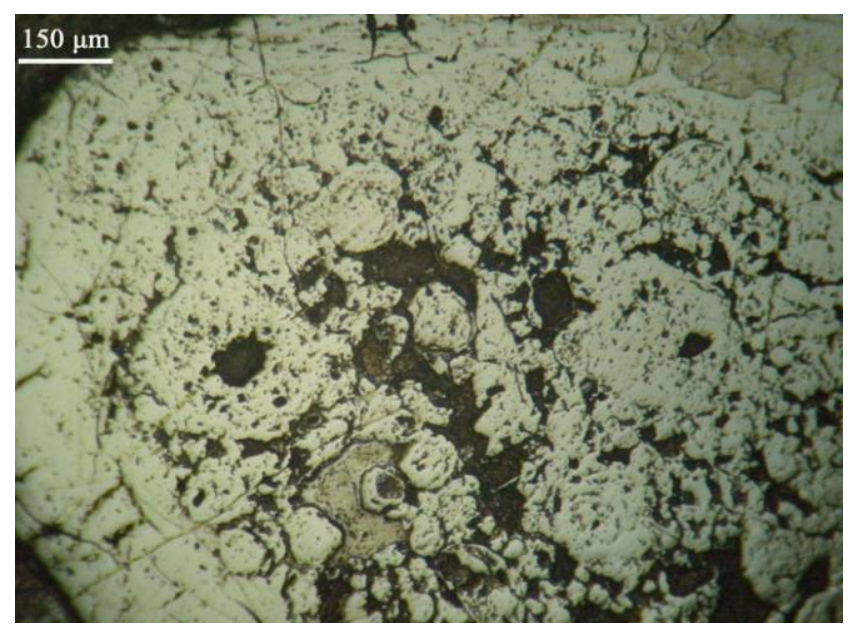

Figure 4. Complex spheroid of hematite with multiple inclusions of ooids and peloids. Sample AK5, Reflected light, // Nicols.

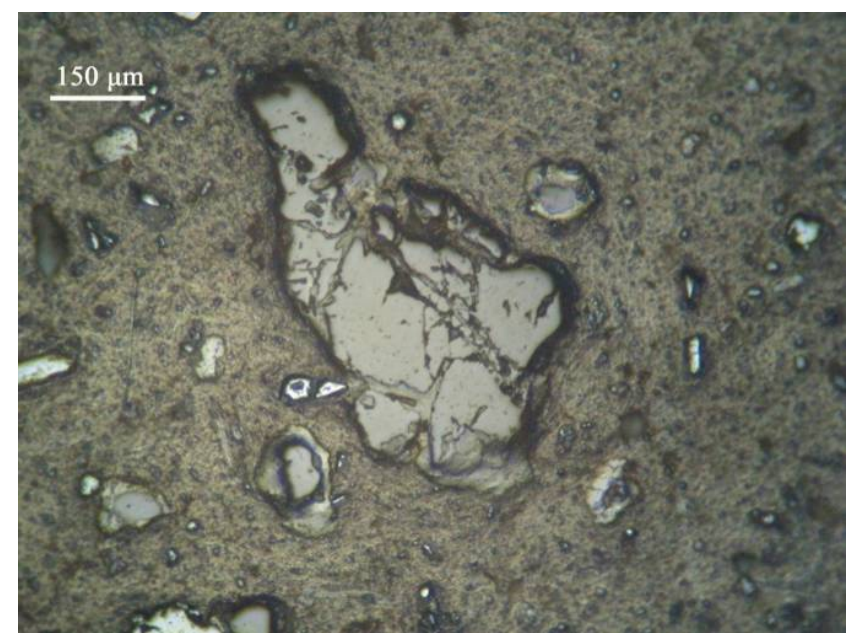

Figure 5. Multiple cracks of chromite crystals with binder material. Sample AK11, Reflected light, // Nicols). 
Table 1. Chemical composition (wt\%) of representative samples from different point of the exposed face.

\begin{tabular}{cccccccccccc}
\hline Location of sample & $\mathrm{SiO}_{2}$ & $\mathrm{Fe}_{2} \mathrm{O}_{3}$ & $\mathrm{Al}_{2} \mathrm{O}_{3}$ & $\mathrm{MgO}$ & $\mathrm{CaO}$ & $\mathrm{MnO}$ & $\mathrm{Cr}_{2} \mathrm{O}_{3}$ & $\mathrm{NiO}$ & $\mathrm{CoO}$ & $\mathrm{LOI}$ & Sum \\
\hline Base of face & 70.17 & 19.44 & 1.44 & 4.11 & 0.58 & 0.02 & 1.10 & 0.84 & 0.05 & 2.38 & 100.13 \\
Middle of the face & 16.86 & 53.36 & 15.04 & 3.78 & 1.19 & 0.07 & 1.79 & 0.52 & 0.08 & 6.95 & 99.63 \\
Top of face & 7.79 & 68.68 & 5.97 & 3.45 & 0.58 & 0.06 & 4.65 & 1.06 & 0.06 & 7.93 & 100.24 \\
\hline
\end{tabular}

\section{Washability Treatment}

The collected bulk sample was crushed in size $-8 \mathrm{~mm}$ using a jaw crusher. The product of the jaw crusher was sieved into fractions $-8+4 \mathrm{~mm},-4+1 \mathrm{~mm},-1+0.250 \mathrm{~mm}$ and $-0.250+0.063 \mathrm{~mm}$. The size fraction $-8+4$ mm was used only for gravimetric separation due to low quantity of this fraction. The rest size fractions $(-4+1$ $\mathrm{mm},-1+0.250 \mathrm{~mm}$ and $-0.250+0.063 \mathrm{~mm}$ ) were used for both magnetic and gravimetric separation tests. The fine fraction $-0.063 \mathrm{~mm}$ is not suitable for these mineral processing tests and therefore it was not used.

The results of chemical analysis on the size fractions produced from the bulk sample are shown in Table 2. The major oxides found are $\mathrm{SiO}_{2}$ and $\mathrm{Fe}_{2} \mathrm{O}_{3}$. The highest $\mathrm{SiO}_{2}$ content is found mainly in the coarser size fraction $(-8.00+4.00 \mathrm{~mm})$, while the highest $\mathrm{Fe}_{2} \mathrm{O}_{3}$ content is present mainly in the fraction $-4.00+1.00 \mathrm{~mm}$. The percentage of $\mathrm{NiO}$ increases as the size fraction decreases.

Table 2. Chemical analysis of size fraction from initial sample.

\begin{tabular}{cccccccccc}
\hline $\begin{array}{c}\text { Size fraction } \\
(\mathrm{mm})\end{array}$ & $\begin{array}{c}\text { Weight } \\
(\%)\end{array}$ & $\begin{array}{c}\mathrm{SiO}_{2} \\
(\%)\end{array}$ & $\begin{array}{c}\mathrm{Fe}_{2} \mathrm{O}_{3} \\
(\%)\end{array}$ & $\begin{array}{c}\mathrm{MgO} \\
(\%)\end{array}$ & $\begin{array}{c}\mathrm{Cr}_{2} \mathrm{O}_{3} \\
(\%)\end{array}$ & $\begin{array}{c}\mathrm{NiO} \\
(\%)\end{array}$ & $\begin{array}{c}\mathrm{CoO} \\
(\%)\end{array}$ & $\begin{array}{c}\mathrm{LOI} \\
(\%)\end{array}$ & $\begin{array}{c}\mathrm{Cumulative} \mathrm{finer} \mathrm{than} \mathrm{size} \\
\text { fraction of NiO }(\%)\end{array}$ \\
\hline$-8.00+4.00$ & 1.19 & 47.04 & 30.47 & 11.48 & 1.47 & 0.47 & 0.07 & 6.87 & 0.83 \\
$-4.00+1.00$ & 49.45 & 11.85 & 70.49 & 1.93 & 3.39 & 0.78 & 0.28 & 7.93 \\
$-1.00+0.250$ & 33.74 & 10.96 & 68.17 & 1.9 & 4.01 & 0.84 & 0.33 & 9.9 & 0.95 \\
$-0.250+0.063$ & 9.48 & 12.38 & 65.09 & 2.01 & 4.32 & 0.88 & 0.31 & 11.14 \\
-0.063 & 6.14 & 16.64 & 58.61 & 2.49 & 3.61 & 1.05 & 0.3 & 12.04 \\
\hline
\end{tabular}

\subsection{Gravimetric Separation}

The gravimetric separation of the ore was carried out using a heavy liquid with density $2.70 \mathrm{~g} / \mathrm{ml}$ which was a mixture of tetrabromoethane and carbon tetrachloride.

The results of the gravimetric separation of the size fractions are shown in Table 3.

According to the results of Table 3, it is clear that the weight percentages of the sinks are generally higher compared to those of the floats for the size fractions $-4.00+1.00,-1.00+0.250,-0.250+0.063$, while in the size fraction $-8.00+4.00$ the floats are higher than the sinks. The results of size fraction $-8+4 \mathrm{~mm}$ are not satisfactory, although the $\mathrm{NiO}$ analysis is $0.82 \%$ in the sinks and $0.36 \%$ in the floats. The interpretation of the dissatisfaction is that the weight distribution of the size fraction is $24 \%$ to the sinks in contrast to $76 \%$ to the floats. This is a fact that a large quantity of $\mathrm{Ni}$ is drawn away to the floats. The above results are also shown by the microscopic examination of this size fraction. The microscopic examination showed that both sinks and floats have more or less the same percentage of bindery material grains, due to the low degree of liberation of this size fraction.

At the size fraction $-4+1 \mathrm{~mm}$, the results were better, but still not satisfactory. The chemical concentration of the $\mathrm{NiO}$ is $0.85 \%$ and $0.57 \%$ in the sinks and the floats correspondingly. The weight distribution in this fraction is $93.7 \%$ in the sinks and $6.3 \%$ in the floats, much better than the $-8+4 \mathrm{~mm}$ fraction. Again the analysis $0.85 \%$ in the sinks is not too bad, but the analysis $0.57 \%$ in the floats shows that a quantity of Ni is lost with the floats.

The results of size fractions $-1+0.250 \mathrm{~mm}$ and $-0.250+0.063 \mathrm{~mm}$ are similar to the previous ones. The chemical analysis of $\mathrm{NiO}$ is $0.96 \%$ in the sinks and $0.74 \%$ in the floats for the size fraction $-1+0.250 \mathrm{~mm}$, while for the size fraction $-0.250+0.063 \mathrm{~mm}$ was $0.94 \%$ on the sinks and $0.80 \%$ in the floats. Although the chemical analysis of $\mathrm{NiO}$ in the sinks $0.96 \%$ and $0.94 \%$ is satisfactory, the $0.74 \%$ and $0.80 \%$ of $\mathrm{NiO}$ in the floats is very high and it is not desirable (Figure 6(a), Figure 6(b)).

The microscopic examination showed that in the sinks there is a large percentage of binder material grains, while in the floats there were a few binder material grains but with smaller size than the ones in the sinks (Figure 7(a), Figure 7(b)). 
Table 3. Results of gravimetric separation.

\begin{tabular}{|c|c|c|c|c|c|c|c|c|c|}
\hline \multirow{2}{*}{ Size fraction } & \multirow{2}{*}{ Products } & \multicolumn{2}{|c|}{ Weight (\%) } & \multicolumn{3}{|c|}{ Chemical analysis (\%) } & \multicolumn{3}{|c|}{ Distribution (\%) } \\
\hline & & of the fraction & of the initial & $\mathrm{SiO}_{2}$ & $\mathrm{Fe}_{2} \mathrm{O}_{3}$ & $\mathrm{NiO}$ & $\mathrm{SiO}_{2}$ & $\mathrm{Fe}_{2} \mathrm{O}_{3}$ & $\mathrm{NiO}$ \\
\hline \multirow{3}{*}{$-8.00+4.00$} & Sinks & 24.3 & 0.3 & 9.04 & 74.42 & 0.82 & 4.67 & 59.68 & 42.28 \\
\hline & Float & 75.7 & 0.9 & 59.30 & 16.17 & 0.36 & 95.33 & 40.32 & 57.72 \\
\hline & Total & 100.0 & 1.2 & 47.07 & 30.34 & 0.47 & 100.00 & 100.00 & 100.00 \\
\hline \multirow{3}{*}{$-4.00+1.00$} & Sinks & 90.9 & 44.9 & 7.57 & 71.88 & 0.85 & 55.55 & 97.39 & 93.68 \\
\hline & Float & 9.1 & 4.5 & 60.18 & 19.13 & 0.57 & 44.45 & 2.61 & 6.32 \\
\hline & Total & 100.0 & 49.5 & 12.38 & 67.06 & 0.82 & 100.00 & 100.00 & 100.00 \\
\hline \multirow{3}{*}{$-1.00+0.250$} & Sinks & 86.1 & 29.1 & 7.31 & 68.58 & 0.96 & 49.41 & 94.71 & 88.96 \\
\hline & Float & 13.9 & 4.7 & 46.49 & 23.79 & 0.74 & 50.59 & 5.29 & 11.04 \\
\hline & Total & 100.0 & 33.7 & 12.74 & 62.37 & 0.93 & 100.00 & 100.00 & 100.00 \\
\hline \multirow{3}{*}{$-0.250+0.063$} & Sinks & 87.3 & 8.3 & 7.88 & 70.15 & 0.94 & 53.67 & 95.72 & 88.97 \\
\hline & Float & 12.7 & 1.2 & 46.70 & 21.53 & 0.80 & 46.33 & 4.28 & 11.03 \\
\hline & Sum & 100.0 & 9.5 & 12.81 & 63.97 & 0.92 & 100.00 & 100.00 & 100.00 \\
\hline-0.063 & Total & 100.0 & 6.1 & 16.64 & 58.61 & 1.05 & 100.00 & 100.00 & 100.00 \\
\hline Grand Total & & & 100 & 13.22 & 64.23 & 0.88 & & & \\
\hline
\end{tabular}

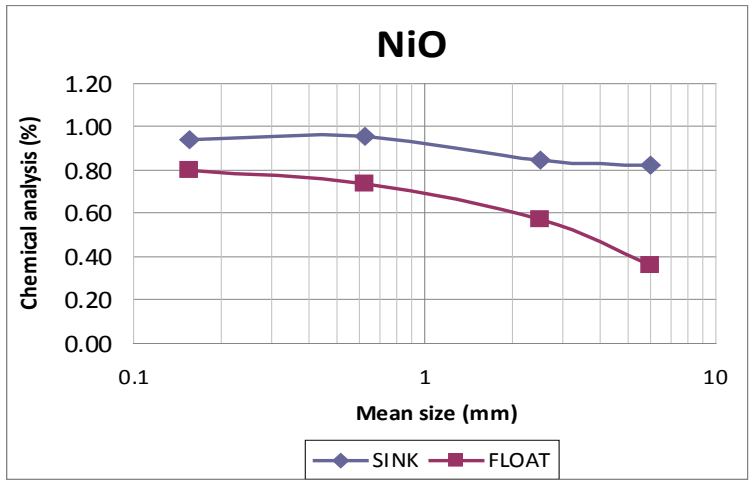

(a)

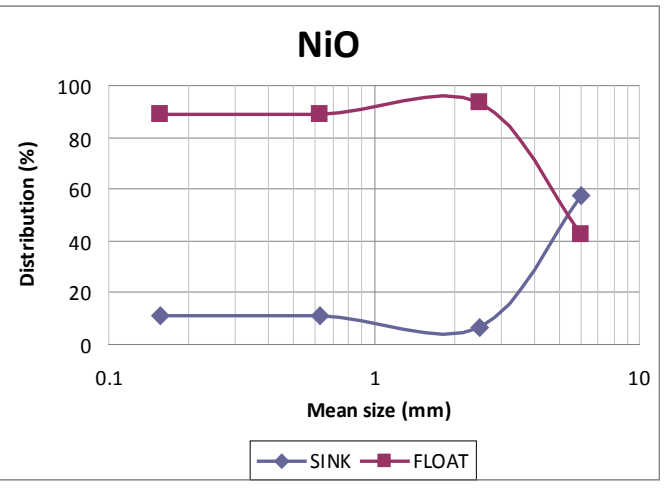

(b)

Figure 6. Chemical analysis (a) and distribution (b) of $\mathrm{NiO}$ according to the mean size of the products obtained from the gravimetric separation.

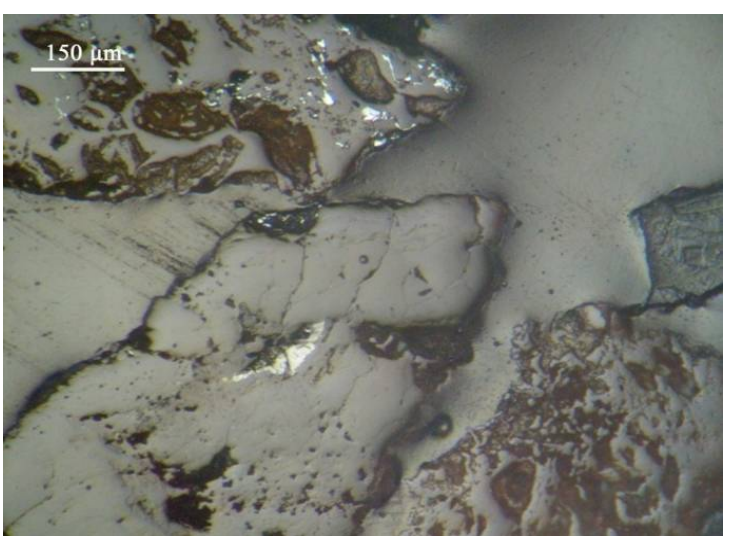

(a)

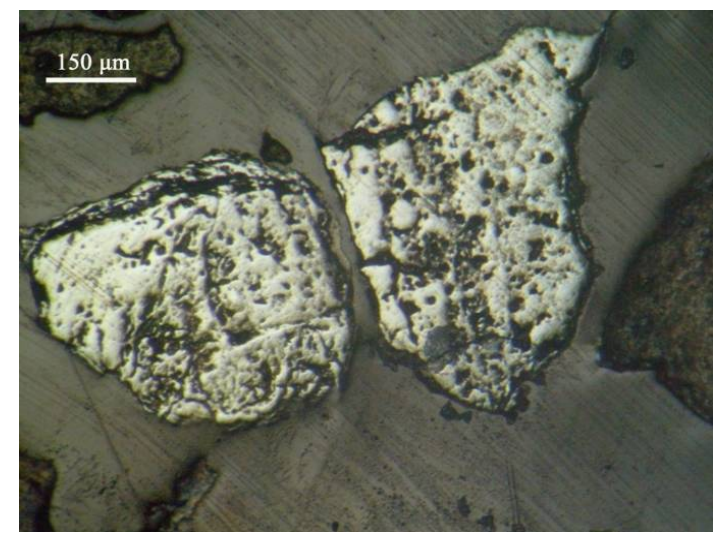

(b)

Figure 7. (a) Quartz grains with traces of hematite (float, size fraction $-1.00+0.250 \mathrm{~mm}$ ), (b) Hematite with grains of binder (sink, size fraction $-1.00+0.250 \mathrm{~mm}$ ). Reflected light, //Nicols. 
The binder material grains in the floats were entrained with quartz material and this fact is justified by the chemical analysis of $0.74 \%$ and $0.80 \%$, respectively. The microscopic investigation showed that the degree of liberation of these size fractions is improved due to the size fraction reduction; however a large proportion of binder material is driven in the floats.

\subsection{Magnetic Separation}

For the magnetic separation of fraction $-4+1 \mathrm{~mm}$ the Perm Roll separator (equipped with permanent magnets) was used. This fraction was separated in three passes with decreasing rotation frequency starting with a rotation frequency of $180 \mathrm{rpm}$. Afterwards the non-magnetics were passed at $140 \mathrm{rpm}$ and finally at $100 \mathrm{rpm}$. In each pass the magnetic product is collected, weighted and assayed, while the non-magnetic is used to feed the next pass. At the final pass, at $100 \mathrm{rpm}$, the last magnetic and the final non-magnetic product were collected, weighted and assayed.

For the fractions $-1+0.250 \mathrm{~mm}$ and $-0.250+0.063 \mathrm{~mm}$ the Induced Roll magnetic separator was used. These fractions were separated initially with a rotation frequency $120 \mathrm{rpm}$ and electric current $\mathrm{I}=2.9$ Amps. From this process two products (a magnetic and a non-magnetic) were collected. The non-magnetic product was passed again by the separator at the same electric current but at a lower rotation frequency of $100 \mathrm{rpm}$. At this pass the final magnetic and the final non-magnetic products were collected.

The results of the magnetic separation of size fractions $-4+1 \mathrm{~mm},-1+0.250 \mathrm{~mm}$ and $-0.250+0.063 \mathrm{~mm}$ are shown in Table 4.

At the fine size fraction $-1+0.250 \mathrm{~mm}$ the separation was better than this of the fraction $-4+1 \mathrm{~mm}$. The chemical analysis of $\mathrm{NiO}$ was $0.90 \%$ in the magnetic product $1,0.83 \%$ in the magnetic product 2 and $0.55 \%$ in the non magnetic product 2.

The microscopic investigation of the products showed that the two first magnetic products have the greatest proportion of binder material grains, while the non magnetic product is composed of quartz grains only (Figure 8(a), Figure 8(b)).

Table 4. Results of magnetic separation.

\begin{tabular}{|c|c|c|c|c|c|c|c|c|c|}
\hline \multirow{2}{*}{ Size fraction } & \multirow{2}{*}{ Products } & \multicolumn{2}{|c|}{ Weight (\%) } & \multicolumn{3}{|c|}{ Chemical analysis (\%) } & \multicolumn{3}{|c|}{ Distribution (\%) } \\
\hline & & of the fraction & of the initial & $\mathrm{SiO}_{2}$ & $\mathrm{Fe}_{2} \mathrm{O}_{3}$ & $\mathrm{NiO}$ & $\mathrm{SiO}_{2}$ & $\mathrm{Fe}_{2} \mathrm{O}_{3}$ & $\mathrm{NiO}$ \\
\hline$-8.00+4.00 \mathrm{~mm}$ & Total & 100.00 & 1.19 & 47.04 & 30.47 & 0.47 & 100.00 & 100.00 & 100.00 \\
\hline \multirow{5}{*}{$-4.00+1.00 \mathrm{~mm}$} & Magnetic 1 & 88.96 & 43.99 & 11.70 & 66.46 & 0.80 & 80.87 & 90.54 & 89.41 \\
\hline & Magnetic 2 & 9.33 & 4.61 & 16.25 & 63.21 & 0.86 & 11.78 & 9.03 & 10.08 \\
\hline & Magnetic 3 & 0.59 & 0.29 & 35.53 & 40.11 & 0.52 & 1.63 & 0.36 & 0.39 \\
\hline & Non magnetic 3 & 1.12 & 0.56 & 65.43 & 4.22 & 0.09 & 5.72 & 0.07 & 0.13 \\
\hline & Total & 100.00 & 49.45 & 12.87 & 65.30 & 0.80 & 100.00 & 100.00 & 100.00 \\
\hline \multirow{4}{*}{$-1.00+0.250 \mathrm{~mm}$} & Magnetic 1 & 86.98 & 29.35 & 10.20 & 68.07 & 0.90 & 73.30 & 90.67 & 88.76 \\
\hline & Magnetic 2 & 9.72 & 3.28 & 16.96 & 55.71 & 0.83 & 13.62 & 8.30 & 9.19 \\
\hline & Non magnetic 2 & 3.29 & 1.11 & 48.06 & 20.41 & 0.55 & 13.08 & 1.03 & 2.04 \\
\hline & Total & 100.00 & 33.74 & 12.10 & 65.30 & 0.88 & 100.00 & 100.00 & 100.00 \\
\hline \multirow{4}{*}{$-0.250+0.063 \mathrm{~mm}$} & Magnetic 1 & 88.44 & 8.38 & 9.82 & 67.19 & 0.90 & 68.01 & 93.23 & 91.09 \\
\hline & Magnetic 2 & 7.76 & 0.74 & 21.36 & 50.78 & 0.86 & 12.98 & 6.18 & 7.71 \\
\hline & Non magnetic 2 & 3.80 & 0.36 & 63.92 & 9.80 & 0.27 & 19.02 & 0.58 & 1.20 \\
\hline & Total & 100.00 & 9.48 & 12.77 & 63.74 & 0.87 & 100.00 & 100.00 & 100.00 \\
\hline$-0.063 \mathrm{~mm}$ & Total & 100.00 & 6.14 & 16.64 & 58.61 & 1.05 & 100.00 & 100.00 & 100.00 \\
\hline \multicolumn{2}{|c|}{ Grand Total } & & 100.00 & 13.24 & 64.33 & 0.84 & & & \\
\hline
\end{tabular}




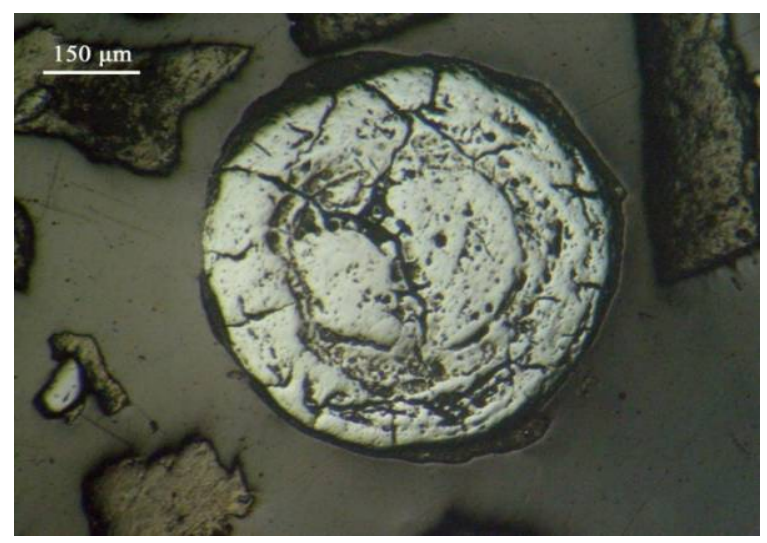

(a)

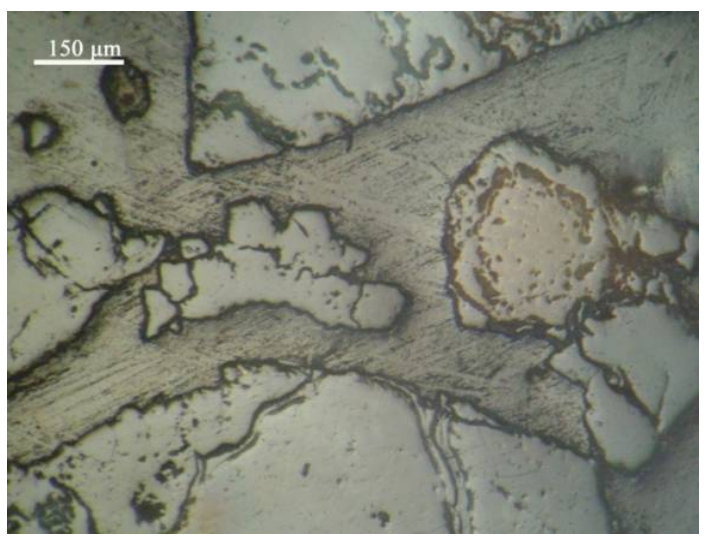

(b)

Figure 8. (a) Ooids of hematite and binder grains (Magnetic product 1, size fraction $-1.00+0.250 \mathrm{~mm}$ ); (b) Quartz grains (Non magnetic product, size fraction $-1.00+0.250 \mathrm{~mm}$ ). Reflected light, // Nicols.

At the fine size fraction $-0.250+0.063 \mathrm{~mm}$ the separation was better than the separation at the fraction $-1+$ $0.250 \mathrm{~mm}$. According to the degree of separation of $\mathrm{NiO}$ (Figure 9) this last separation is the one that has given the best results. The degree of separation (n) can be found by the chemical analysis of the $\mathrm{NiO}$ (in this paper) of the initial sample (f), the magnetic products (c) and the non-magnetic products (t) using the equation:

$$
n=\frac{c_{\max } \cdot(c-f) \cdot(f-t)}{f \cdot\left(c_{\max }-f\right) \cdot(c-t)}
$$

where $c_{\max }=$ the chemical analysis of the phase containing in the $\mathrm{NiO}$ [12].

The chemical analysis of $\mathrm{NiO}$ was $0.90 \%$ in the magnetic product $1,0.86 \%$ in the magnetic product 2 and $0.27 \%$ in the non magnetic product 2 . The microscopic investigation on the products showed that the two first magnetic products have the greatest proportion of binder material grains, the non magnetic product composed of quartz grains only.

Microanalyses were performed on ooids and peloids from nickeliferous ores of Agios Ioannis and Marmeiko (Locris-Greece) where the $\mathrm{NiO}$ chemical analysis ranging between 0.20 - $1.06 \mathrm{wt} \%$ [13].

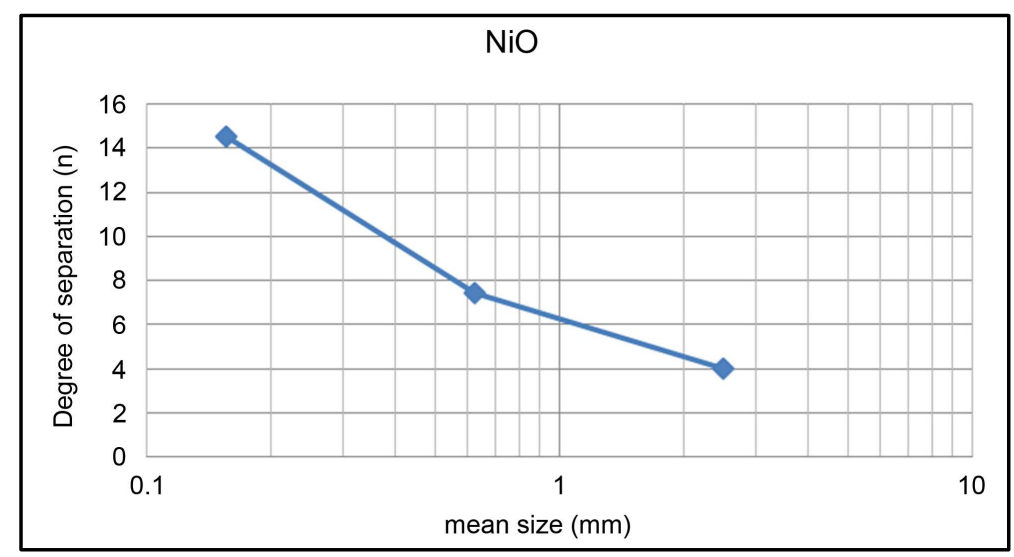

Figure 9. Degree of the separation of $\mathrm{NiO}$ according the mean size of magnetic separation products.

\section{Discussion and Conclusions}

The nickeliferous ore of Nome area (N.E. Albania) is found as ore bed over ultramafic rocks (harzburgite-serpetinite). The upper part of ultramafic rocks is developed by a saprolite zone and over this is a thin layer of clays zone. Above that there is a pisolitic zone (which is the thickest layer of the deposit) and it is covered by limestone of Early Cretaceous. 
The major minerals of the nickeliferous ore of Nome area are hematite, goethite and quartz, while the minor ones are chlorite (clinochlore and nickeliferous chlorite), chromite, lizardite, kaolinite and calcite. The ferrous minerals are mostly found in a form of spheroid particles like: ooids, pisoids, peloids and complex spheroids. The gradual transformation of goethite to hematite is also observed, due to dehydration. Nickel can be found in the binder material of the ore and especially in clinochlore and nickeliferous chlorite. According to the microanalysis of nickeliferous chlorite, the main nickel bearing mineral on the nickeliferous iron ore from Komnina Vermion Area (N.W. Greece), an ore body similar to Nome concentrations of NiO are in the range between 3.07 - 5.26 wt\% [14]. The microscopic investigation showed that the ore has an allotriomorphic inequigranular tissue and an oolithic-pisolitic texture.

It is safe to say that before any washability treatment the three smaller size fractions which can be summed up to one concentrate which will have an analysis of $\mathrm{NiO}$ of $0.95 \%$. So a product could be arisen with better chemical analysis on $\mathrm{NiO}$ just by crashing the source material and keeping the whole $-1.00 \mathrm{~mm}$ size fraction. The remaining material $(+1.00 \mathrm{~mm})$ can be managed through mineral processing procedures in order to give a more satisfying Ni product.

As far as the washability treatment, it has seen that in general the gravimetric methods give better results than the magnetic, specifically the increase of $\mathrm{NiO}$ chemical analysis is better at the gravimetric method. Furthermore it is obvious that the percentage of $\mathrm{NiO}$ in all size fraction products is poor.

Particularly, the gravimetric separation showed that the sink of $-8.00+4.00 \mathrm{~mm}$ size fraction has a chemical analysis of $\mathrm{NiO} 0.82 \%$, which is very poor for a nickel product but it is a retrieval from the initial product. The rest of the size fraction products had a slight increase of $\mathrm{NiO}$ chemical analysis which is not considered so beneficial. The minor increases of $\mathrm{NiO}$ concentrate in the products of the gravimetric separation are attributed to the insufficient liberation of the binder material of the ore.

The results of magnetic separation showed that, at the size fraction $-4+1 \mathrm{~mm}$ the majority of nickel is detected in the magnetic products, but again the increase of the $\mathrm{NiO}$ chemical analysis was not satisfactory. The size fractions $-1+0.250 \mathrm{~mm}$ and $-0.250+0.063 \mathrm{~mm}$ give similar results to the previous one. The microscopic investigation showed that the greater quantity of binder material grains goes to the magnetic products.

The greater chemical analysis of $\mathrm{NiO}$ was found in the -0.063 size fraction, which didn't undergo any washability treatment and it is $1.05 \%$. This is linked with the presence of nickel in particular phyllosilicates minerals, which are found in the binder of the ore and due to the process of crushing and sieving are driven to finer size fractions.

A significant quantity of nickel has been also recognized as separate component of ooids and peloids of various deposits, making it almost impossible to recover with the mineral processing methods used.

The results of the separations showed that the magnetic method in the two fine size fractions was not the most efficient by the nickel washability treatment. The gravimetric separation has given slightly better results. Generally the washability treatment with gravimetric and magnetic separation methods of this ore did not gave satisfactory results and it is proposed to keep the fine size fraction $(-1.00 \mathrm{~mm})$ as it is and the coarser $(+1.00 \mathrm{~mm})$ to proceed by other mineral processing methods.

\section{Summary}

The research methods that were used for the mineralogical investigation of the nickeliferous ore of Nome area (N.E. Albania) were mineralogical analysis using x-ray diffraction and ore microcopy, chemical analysis using $\mathrm{x}$-ray fluorescence, while the washability treatment was performed by gravimetric and magnetic separation.

The major minerals of the nickeliferous ore of Nome area are hematite, goethite and quartz, while the minor ones are chlorite (clinochlore and nickeliferous chlorite), chromite, lizardite, kaolinite and calcite. The microscopic investigation showed that the ore has an allotriomorphic inequigranular tissue and an oolithic-pisolitic texture.

The chemical analysis showed that $\mathrm{NiO}$ was less than $0.95 \%$ in the size fractions greater than $0.063 \mathrm{~mm}$, while the $-0.063 \mathrm{~mm}$ has a concentration of $\mathrm{NiO} 1.05 \%$.

The results of the separations showed that the gravimetric separation has given slightly better results than the magnetic one. Due to not satisfactory results of the washability treatment with gravimetric and magnetic separation methods, it is proposed to keep the fine size fraction $(-1.00 \mathrm{~mm})$ as it is and to treat the coarser fraction $(+1.00 \mathrm{~mm})$ by other mineral processing methods. 


\section{References}

[1] Apostolikas, A. (2009) Nickel Deposits. Efyra Publications (in Greek).

[2] Dalvi, A., Bacon, G. and Asborne, R. (2004) The Past and the Future of Nickel Laterites. PDAC 2004 International Convention, Trade Show and Investors Exchange, 7-10 March 2004.

[3] Kuck, H.P. (2005) US Geological Survey, Mineral Commodity Summaries. http://minerals.usgs.gov/minerals/pubs/commodity/nickel/nickemcs05.pdf

[4] Elias, M. (2002) Nickel Laterite Deposits-Geological Overview, Resources and Exploitation. Centre for Ore Deposit Research, University of Tasmania, Special Publication, 4, 205-220.

[5] Alevizos, G., Apostolikas, A. and Repouskou, E. (2011) Mineralogical-Petrographic and Geochemical Investigation of the Nickeliferous Lateritic Deposit of Nome (N.E. Albania). Mineral Wealth, 161, 7-21 (in Greek).

[6] Nickel in Albania www.mete.gov.al/upload/nickel.pdf

[7] Dilek, Y., Shallo, M. and Furnes, H. (2010) Rift-Drift, Seafloor Spreading, and Subduction Tectonics of Albanian Ophiolites. International Geology Review, 47, 147-176.

[8] Thorne, R., Roberts, St. and Herrington, R. (2012) The Formation and Evolution of the Bitincke Nickel Laterite Deposit, Albania. Mineral Deposits, 47, 933-947. http://dx.doi.org/10.1007/s00126-012-0411-X

[9] Gawlick, H.-J., Frisch, W., Hoxha, L., Dumitrica, P., Krystyn, L., Lein, R., Missoni, S. and Schlagintweit, F. (2008) Mirdita Zone Ophiolites and Associated Sediments in Albania Reveal Neotethys Ocean Origin. International Journal of Earth Sciences (Geol Rundsch), 97, 865-881. http://dx.doi.org/10.1007/s00531-007-0193-Z

[10] Pamic, J. (1983) Considerations on the Boundary between Lherzolite and Hasburgite Subprovinces in the Dinarides and Northern Hellinides. Ofioliti, 8, 153-163.

[11] Hoxha, M. and Boullier, A.-M. (1995) The Peridotites of the Kukes Ophiolite (Albania): Structure and Kinematics. Tectonophysics, 249, 217-231. http://dx.doi.org/10.1016/0040-1951(95)00016-G

[12] Stamboliadis, E. (1984) Measure of Separation. Mineral Processing and Extractive Metallurgy, Institution of Mining and Metallurgy, Transactions Section C, 93.

[13] Alevizos, G. and Muecke, A. (2001) Erzpetrographisch-mikroanalytische Untersuchung und Genese der sedimentaeren Eisennickelvorkommen von Agios Ioannis und Marmeiko (Lokris-Griechenland). Neues Jahrbuch für Mineralogie Abhandlungen, 176, 67-88.

[14] Alevizos, G. and Repouskou, E. (2011) Ore Microscopy and Microanalysis of the Nickeliferous Iron Ores from Komnina Vermion Area (N.W. Greece). Geomaterials, 1, 44-48. http://dx.doi.org/10.4236/gm.2011.12008 
Scientific Research Publishing (SCIRP) is one of the largest Open Access journal publishers. It is currently publishing more than 200 open access, online, peer-reviewed journals covering a wide range of academic disciplines. SCIRP serves the worldwide academic communities and contributes to the progress and application of science with its publication.

Other selected journals from SCIRP are listed as below. Submit your manuscript to us via either submit@scirp.org or Online Submission Portal.
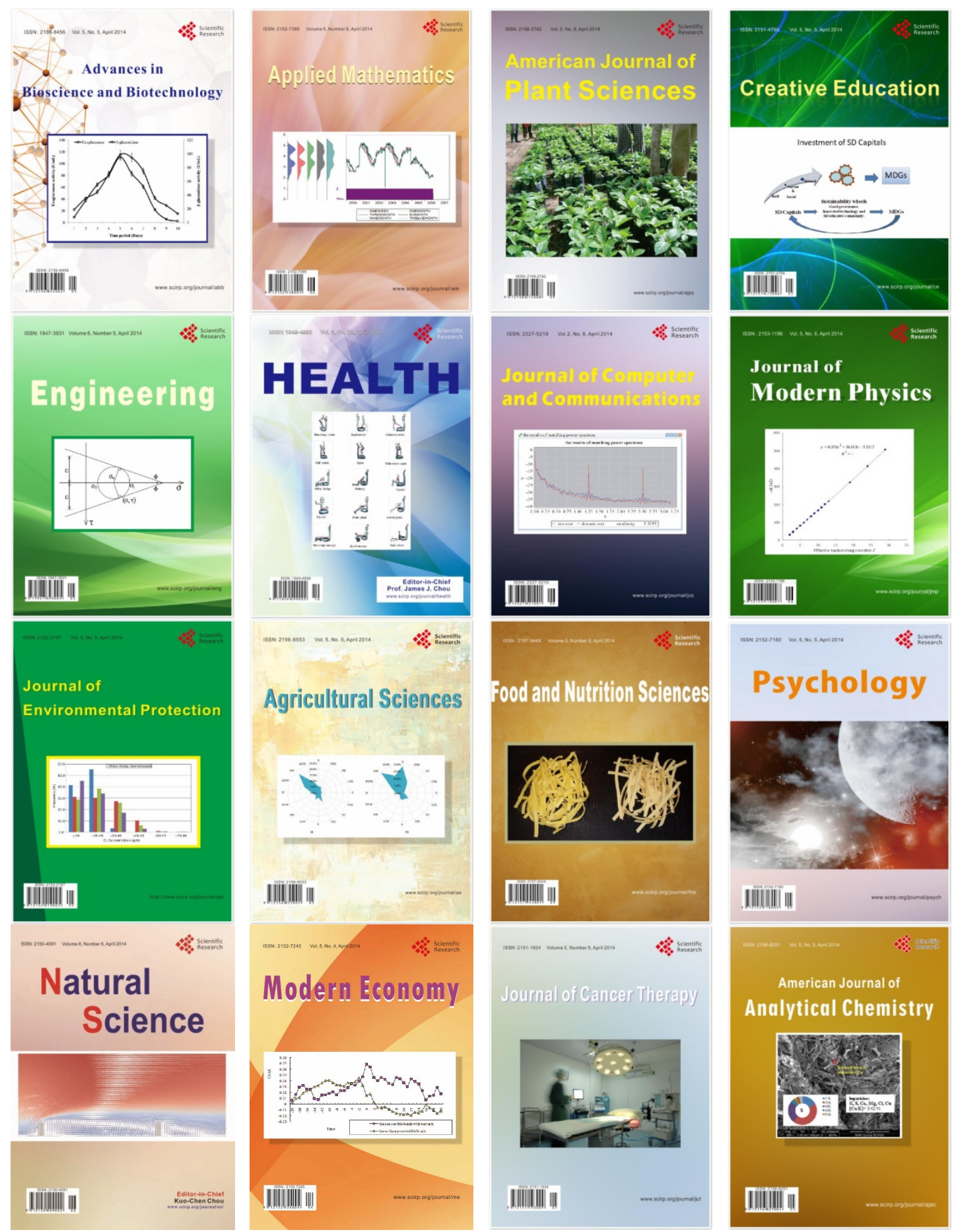